\title{
SPACES OF POSSIBILITY: CONTRIBUTIONS OF LOCAL THEOLOGIES
}

\author{
Gerald M. BOODOO
}

\section{The Recognition of Local Theologies}

The growing concern among Christians of the Third World about the structure of domination and injustice keeping a wide gap between the rich and the poor among the nations and within the nations was followed by an equally important concern about the continuing dependence of Third World theologies on models inherited from the affluent West. These models have been incapable of challenging and overcoming the injustice and of developing new models of theology which would interpret the Gospel in a more meaningful way to the peoples of the Third World and promote their struggle for liberation. In particular, these new models would promote a deeper rooting of the Christian message within the cultures of the people, in respectful dialogue with the persons and their traditional/popular religions. This was the background of the meeting called at Dar-es-Salaam in August, 1976 for an Ecumenical Dialogue of Third World Theologians.

The Experience of fellowship as well as the common concern for doing theology in a new way relevant for the Third World context, gave theologians a sense of being together in spite of their difference of theological orientation. They found this experience so worthwhile that they decided there should be more ecumenical gatherings of Third World Christians on their social, political, economic, religious, and cultural realities for the purpose of strengthening the liberation struggle.

Accordingly, they decided to organize themselves into an association of Third World theologians. The Third World refers to the context of the poor and the oppressed in the continents of Africa, Asia and Latin America, the regions of the Caribbean and the Pacific, the peoples 
of the diaspora from Africa, Asia, and Latin America, and all marginalized peoples in other parts of the world. ${ }^{1}$

Some of you may or may not be familiar with this, but it is the preamble to the constitution and by-laws of EATWOT, the Ecumenical Association of Third World Theologians. As my brother Shanthikumar Hettiararchchi from Sri Lanka, reminded us at our last EATWOT meeting in Salvador da Bahia, Brazil, last year, the "third" in third world is to be understood as an alternative to the first and second world, represented by capitalism and socialism (the USA and the Soviet Union at that time), an alternative that works towards creating another possible world. So, EATWOT created avenues for alternative theologies and even more importantly, gave voice to many local theologies around the globe. It might be important for us to look at what was desired in this expression of hope to see what has actually been achieved 40 years later. In looking at the preamble one can identify a few significant points of concern which I will briefly comment on and perhaps return to later.

1. "The structure of domination and injustice keeping a wide gap between the rich and the poor among the nations and within the nations." This highlights the policies of neoliberal capitalism that continue to exacerbate and heighten this issue and our socio-political, cultural and economic realms which seem to willfully not address this growing problem. It's as though there is agreement that the poor will be with us always, so why bother? In the meantime, it feeds into the entitlement culture of our youth, the continued denigration of inferiorized sections of our populations such as ethnic minorities, gender dissimilarities and power differentials, and so-called primitive cultures and religions.

2. "The continuing dependence of Third World theologies on models inherited from the affluent West." The pervasiveness of coloniality is by now, I hope, a wellaccepted fact. I think this quote from the Tunisian Jew Albert Memmi in his younger intellectual work is apt:

We have seen that colonization materially kills the colonized. It must be added that it kills him spiritually. Colonization distorts relationships, destroys or petrifies institutions, and corrupts men, both colonizers and colonized. To live, the colonized needs to do away with colonization. To become a man, he must do away with the colonized being that he has become. If the European must annihilate the colonizer within himself, the colonized must rise above his colonized being. ${ }^{2}$

${ }^{1}$ Preamble to the Constitution and By-Laws of the Ecumenical Association of Third World Theologians upheld at their 2001 General Assembly in Quito, Ecuador.

${ }^{2}$ Albert Memmi, The Colonizer and the Colonized (Boston: Beacon Press, 1965), 151. 
I will address this point later but it seems clear that the inability to rise above our colonized beings and the structures of coloniality remain prevalent.

3. "Models have been incapable of challenging and overcoming the injustice and of developing new models of theology which would interpret the Gospel in a more meaningful way to the peoples of the Third World and promote their struggle for liberation." The advent of liberation theology did suggest there were theological avenues to address this, but even liberation theology cannot seem to rise above its colonized being and contemporary theological education and curricula seem to enshrine the cultural and epistemological perspectives of a colonial organization. Local theologies have struggled with this and straddle the very fluid line between wanting to remain in concert with a universal impulse yet stay shy of a universalizing hegemony. It remains a dynamic negotiation that can be misunderstood by any participant in the negotiation; and negotiation it is, not a with us/against us proposition precisely because of the contemporary hyperdifferentiation of our contexts.

4. "These new models would promote a deeper rooting of the Christian message within the cultures of the people, in respectful dialogue with the persons and their traditional/popular religions. ” In his encyclical Fides et Ratio, John Paul II writes:

This simple statement contains a great truth: faith's encounter with different cultures has created something new. When they are deeply rooted in experience, cultures show forth the human being's characteristic openness to the universal and the transcendent. Therefore, they offer different paths to the truth, which assuredly serve men and women well in revealing values which can make their life ever more human. Insofar as cultures appeal to the values of older traditions, they point-implicitly but authentically-to the manifestation of God in nature, as we saw earlier in considering the Wisdom literature and the teaching of Saint Paul. ${ }^{3}$

It is heartening to see the growth of interfaith/religious dialogue, comparative theologies, and other theological inquiries into understanding and engaging varied and multiple religions and religious contexts. There is increased dialogue and attempts at rooting Christianity in various cultures. One can of course look to the efforts of inculturation throughout our global Christian contexts. But one wonders, as Archbishop Emeritus Kwame Sarpong of Ghana has remarked, how much of it is simply cosmetic and not a vigorous incarnation in the context-possibly for fear of losing the "universal" character of a particular denomination? Is there a fear of the "something new" created by faith's encounter with different cultures? An important aspect of this is our understanding of indigenous epistemologies. Let's leave aside the vast indigenous populations outside North America and focus just on the indigenous populations of this context. How seriously have we taken the suggestions of Vine

${ }^{3}$ John Paul II, Fides et Ratio (September 14, 1998), §70, http://w2.vatican.va/content/johnpaul-ii/en/encyclicals/documents/hf_jp-ii_enc_14091998_fides-et-ratio.html. 
Deloria and George Tinker? ${ }^{4}$ Have we re-oriented our theologies based on the insights given by their traditions that have occupied this space of the Americas way before colonial/modern technological conquest? Our curricula are still fashioned by a universalizing religious epistemology geared towards a self-sustaining religiouspolitical hierarchy and an almost incestuous network of theologizing. Ecofeminism and ecotheologies do offer some hope here but we are left to see how they play out in a globalized economy.

5. "The Third World refers to the context of the poor and the oppressed in the continents of Africa, Asia and Latin America, the regions of the Caribbean and the Pacific, the peoples of the diaspora from Africa, Asia, and Latin America, and all marginalized peoples in other parts of the world." My mention of my colleague Shanthi earlier was to underscore that still today, and perhaps now more than ever, the desire for alternatives that address the non-hegemonic hopes and aspirations of many groups of people in our world is palpable. This is seen most clearly in the social movements and especially the World Social Forum (WSF), begun in 2001 in Brazil as an alternative to the World Economic Forum's annual meeting in Davos, Switzerland. This social forum has as its common theme the cry made famous by the Zapatistas that Another World is Possible and, except for a meeting in Montreal in 2016, meets in the Global South (Asia, Africa, Latin America) usually every two years to share ideas and activities toward making this new world possible. Since 2005, the World Forum on Theology and Liberation (WFTL) has been part of the WSF trying, sometimes more successfully than others, to inject theological and religious reflection into the ideas and discussions of the social movements that by and large think religion and theology is a big part of the problem. However, there is a growing sense that the contexts of the poor and oppressed all over our globe are becoming more intolerable and unmanageable.

Going over the five issues raised by EATWOT's constitution since the 1970's, we see that there still is a lot of work to be done and that the rationale for EATWOT's existence is very much alive. Apart from some progress in the areas of inculturation, interfaith/religious dialogue and advances in liberation theology, quite a lot of work still needs to be done in the other areas and in the more prominent areas of ecofeminism and decoloniality. Yet, in recent years there has been a lot of discussion among its members on whether to let EATWOT pass gracefully. So much so, that, at the last meeting in Salvador last year, the association changed its structure significantly because of the lack of interest in the association among its members and the difficulty in funding, arranging and holding international meetings. Without sounding alarm, for all intents and purposes, EATWOT is no longer as prominent as it was, even though one can argue that today more than ever, we need global links of solidarity with our

${ }^{4}$ Vine Deloria, God is Red: A Native View of Religion, $30^{\text {th }}$ Anniversary Edition (Golden, CO: Fulcrum Publishing, 2003); George E. Tinker, American Indian Liberation: A Theology of Sovereignty (Maryknoll, NY: Orbis Books, 2008); Clara Sue Kidwell, Homer Noly, George E. Tinker, eds., A Native American Theology (Maryknoll, NY: Orbis Books, 2001). 
brothers and sisters throughout our world engaged in the struggle for faith-filled life, human dignity and hope.

To my mind, EATWOT has been hugely successful and has substantially fulfilled part of its mission, in that it gave impetus and voice to many theological movements around the world that have since mobilized and organized into functioning associations and societies. So, while there is still a lot of work to be done regarding the points raised by EATWOT's preamble, a lot of that work is being engaged by the multiple, active local groups of theologians and activists in Asia, Africa, Latin America, North America and Europe, energized by EATWOT's call to solidarity among third world theologians. Perhaps this is where the World Forum on Theology and Liberation comes in, designed to work with the various local groups of theologians through its international committee, it tries to network these disparate groups around the WSF theme that another world is possible. It also wants theology to be part of, and considered to be part of, the social movements to effect epistemological, practical and spiritual change. The CTSA unfortunately, has not taken up the invitation to be part of this network, but I do hope this will be rectified in the near future. In my travels in Africa, Asia, Latin America and the Caribbean and in my encounters with groups (established and nonestablished) in the US and Canada, there are vibrant societies working and struggling to accomplish exactly what EATWOT was formed to do. What remains the biggest challenge is coming together, whether online or physically, to share the differing and common struggles of each group.

\section{Local Theologies Speak}

In my thirty and more years of listening to and engaging local theologies, and theologians from around the world, four main issues remain constant though dynamic, in that the questions related to them have changed over time. The list is not new but their persistence over the years indicates our need to address them more completely. They are (i) social-political-economic-cultural factors, (ii) gender power differentials, (iii) perspectives on the environment and its degradation, and (iv) interfaith/religious relations.

\section{Social-Political-Economic-Cultural Factors}

The bundling of these factors together is not meant to reduce or minimize their impact separately but to acknowledge how much they bleed into each other and present a unified stance in determining the welfare and livelihood of people. I still remember as a teen in the 1970s the excitement brought by the adoption of liberation theology in parts of Latin America and the Caribbean. Living in a new post-colonial society in the Caribbean in those days, it seemed, along with the Second Vatican Council, to augur a future of justice and equality for all, based on Christian principles. Our churches, at least in the Caribbean and in other parts of the world, began to involve the laity and looked to deepen our relationships with local cultures and other religions. There was a clear sense that our social, political, economic and cultural structures needed to prioritize the marginalized and victimized in our midst. However, like many revolutions, the same tools used for oppression were utilized for liberation and the 
resultant replicative ideology of our political and religious systems only presented more of the same but in different packaging. I addressed some of this in my presentation here at the CTSA in 1997 on the forced context of theologizing and it still seems relevant today.

I was struck at the time how many contexts, and in particular the Caribbean, were and are ones that have forced people to ground themselves in contexts that are not their own. No doubt globalization has exacerbated this and that is perhaps why today many people are able to navigate multiple relationships at different levels. In exploring this further, I wanted to make this understanding of a forced context theologically relevant and I sought to do this by turning traditional philosophical theological categories on their head in order to provoke an alternate consciousness.

The first category I wanted to "turn" was the traditional understanding of free will. I wanted to show that the genuine option for the suffering person is not the result of reasonable choices made based on an exercise of the will. Even further, that will and freedom are not compatible, because meaningful human action is based not on the possibility and availability of choice but on the lack thereof. We do theology because it must be done. We have a church because we must witness to God's grace in the midst of our suffering, not merely because a church is a nice thing to have. Our actions are determined not by the possibilities before us but by the urgency of our present condition. Freedom is, therefore not dependent on the possibility of new and alternative structures, but on our resistance to the present conditions of suffering and exploitation that creates cracks which we open and expand to forge "something new."

The second understanding I wanted to adjust was the notion that freedom and hope are necessary partners. If the condition of being forced propels us to identify and move towards what is urgent in our existing and continuing situation, then hope can often serve to deprive us of an understanding of our context rooted in the here and now. It would be better to fully recognize our forced and despairing situation created by exploitation and suffering, than to rely on a hope that might deceive and paralyze us. Hence the provocative statement that we should understand freedom not in the light of hope but in the context of despair. This was not meant as a statement of hopelessness more than a clear recognition of the reality within which we are situated.

The third issue I wanted to find a way around was the very individualistic way in which we understand what it means to be human and, by extension, faith. This is based on the classical understanding of our having some essential human nature and identity grounded in the individual as a singular being. Hence, I claimed that the forced context calls for the non-essentiality of the human condition in an attempt to underscore that our identities take shape as a result of differentiation. Only because of the other person(s) do I have meaningful human existence. This is why I claimed that the notion of the non-essentiality of the human condition forces us to strive towards the realization of a condition which allows us to be most fully human and most fully free, that is, in solidarity.

Finally, forced contexts borne out of exploitation and suffering always tend to equate religion, religious expression and theology with the impulse toward survival. Sometimes this loses sight of the Christian fact that salvation at times denies even the possibility of mere survival. Indeed, at times, salvation demands death, the closure of all possibility of surviving but the opening of the possibility for solidarity and 
transformation. Our equation of religion with survival, and now more so with success, has robbed us of the important distinction to be made between survival and salvation. The religion of survival speaks the language of freedom but remains a slave religion replicating the desires and aspirations of the dominant powers.

As I revisit these notions of the forced context, I realize that it is not enough simply to play gymnastics with established categories, as helpful as it may be in adjusting minds, but it is necessary to find descriptive analyses that give fuller expressions of contexts. This is why I think more and more theologians are beginning to pay closer attention to decolonial thinking and recognizing its potential in both decolonizing our theology as well as creating avenues for realistic and feasible epistemologies, active engagement and spiritualities. It is a difficult process however, since, as my earlier quote of Memmi suggests, it is difficult for our theologies and theologians to rise above our colonized beings and decolonial thinkers (who are not theologians) in general believe that it is impossible for theologians and their institutions, which exist hand in hand with coloniality, to engage decoloniality with integrity. Let me give what can only be a brief overview of decolonial thinking for those who may not be familiar with it.

Over the past decade and more, some scholars in Latin American Studies have been filling in the gap in Latin American studies on its colonial history. Their point of contention is that when one thinks of modern colonialism one easily refers to Africa, Asia, and the Caribbean but not so easily to the Americas and specifically Latin America. ${ }^{5}$ As these scholars began to investigate this submerged reality, they discovered structural patterns of thinking and acting that appeared to be present in what they term the modern project - the expansion of selective European ways of thinking and acting designed to consolidate European hegemony. The structures they uncovered and the mode of thinking they have promoted are now termed coloniality and decolonial thinking. For our purposes, there are four main points I want to make with regard to decolonial thinking.

The first is that we need to understand that modernity has created a world system that for the first time in the history of the world has linked all (or virtually all) parts of the world and subsumed them into a connected system. Along with this comes the realization that not everyone and everywhere have benefited from these connections. There is a dark side to this modern system of coloniality so that you have those who benefit from the modern project, those who are "inside" modernity and wield the power of modernity and who can too easily be blinded to the millions who are negatively affected by modernity, who are "outside." This "outside" of modernity is termed the "colonial difference." By colonial difference is meant "the place and experiences of those who have been the object of inferiorization on the part of others who, in the midst of the colonial endeavor, have come to consider themselves to be superior. It is a place

${ }^{5}$ See Mabel Morana, Enrique Dussel, Carlos Jauregui, eds., Coloniality at Large: Latin America and the Postcolonial Debate, (Durham, NC: Duke University Press, 2008); Walter D. Mignolo and Catherine Walsh, On Decoloniality: Concepts, Analytics, Praxis (Durham, NC: Duke University Press Books, 2018). 
and experience constituted as an exteriority to modernity according to a negative logic (a logic of inferiorization). ${ }^{\prime 6}$

Second, there is a "coloniality of power"7 which privileges and enshrines EuroAmerican thinking by constituting itself in (i) the classification and reclassification of the planet population, especially along racial, civilizational and evolutionary lines (the concept of culture becomes crucial in this task); (ii) institutional structures which function to articulate and manage such classifications (state, university, church, etc.); (iii) the definition of spaces appropriate to such goals; and (iv) an epistemological perspective that articulates, legitimates and channels its production of knowledge. Walter Mignolo explains that "Eurocentrism becomes, therefore, a metaphor to describe the coloniality of power from the perspective of subalternity. From the epistemological perspective, European local knowledge and histories have been projected to global designs."

Third, decolonial thought seeks to produce knowledge formed from the colonial difference. What is needed is a new way of thinking, not new ideas. As such, if one speaks from the perspective of the colonial difference, one also speaks from what Mignolo calls the "colonial wound" and therefore decolonial thought and practice does privilege knowledge from these spaces of oppression, the victims of modernity, but with the realization that even though it is produced from "outside" modernity it still is linked to the modern project. The colonial wound is created by coloniality. So decolonial thought gives rise to an ethics and a politics of pluriversality. Standing in opposition to global and totalitarian designs created in the name of universality (which usually means a particularity claiming to be universal), pluriversality is an attempt to make visible and viable a multiplicity of knowledges, forms of being, and visions of the world. "Pluriversality is equality-in-difference, the possibility that many worlds can fit in one world. It is the future alternative to modernity/coloniality." thinkers see this as occurring across many disciplines and many facets of life, hence they assert the "transdisciplinary" and "transcultural" nature of decolonial thinking. This mixture of perspectives works to unmask the "purity" of disciplines and the socalled "universality" of modernity.

Fourth, though decolonial thinking speaks about the "inside" and "outside" of modernity, these are markers designed to explain the colonial difference and colonial wound. They are not to imply that there is a point of view that stands outside of the modern project looking in. In fact, decolonial thinking insists that it is impossible to have a vantage point from which one can view the goings on of the modern project, there is no epoche as early phenomenologists would say. This means that we all

${ }^{6}$ Gregory A. Banazak and Luis Reyes Ceja, "The Challenge and Promise of Decolonial Thought to Biblical Interpretation," Postscripts 4, no. 1 (2008): 116.

${ }^{7}$ Cf. Anibal Quijano, "Coloniality of Power, Eurocentrism, and Social Classification", in Coloniality at Large: Latin America and the Postcolonial Debate, ed. Mabel Morana, Enrique Dussel, Carlos A. Jauregui (Durham, NC: Duke University Press 2008), 181-224.

${ }^{8}$ Walter D. Mignolo, Local Histories/Global Designs: Coloniality, Subaltern Knowledges, and Border Thinking (Princeton, NJ: Princeton University Press, 2000), 17.

9 Banazak and Ceja, "The Challenge and Promise of Decolonial Thought to Biblical Interpretation," 118. 
understand the workings of coloniality by already experiencing it and partaking in neocolonial bounty as a postcolonial or anticolonial human agent. Franz Hinkelammert refers to this as the "privileged exploited", and Gayatri Spivak calls this "neocolonizing anticolonialism." 10 In other words, in working to decolonize, we must be aware of our complicity and use of colonial methodologies, languages, and epistemic locations and the trap of substitutive ideology. This might be the most important aspect of decolonial thinking to my mind, since it does not set itself up as the answer to the problems of modernity but as a way of de-linking accustomed relationships with a view to relinking in multiple, relative and admittedly impure ways.

As an aside, let me also briefly mention how decolonial thought differs from postmodern and postcolonial thinking. The postmodern debate, as its name suggests, still is a debate situated in the heart of modernity and is an inner modern debate attempting to rekindle enlightenment principles in non-dogmatic or non-overarching narrative form. Despite this, it still holds to the core belief that the European enlightenment is the measure by which one determines preference for food, culture, language, music, business and education. It is still heavily inscribed with the coloniality of power and for all its intentions, is unable to seriously address the colonial wound and the millions of people affected by it. Decolonial thought rejects the idea that discourse generated from the inside of modernity can effectively address the colonial difference. Postcolonial thought, though similar to decolonial thought, tends to be, again as the name implies, critical thinking in response to the aftermath of colonialism in previously colonized nations after "independence." Such thinking is uniformly anticolonial and focuses on issues of identity, politics and social construction in postcolonial contexts. Its aim is to forge reasoned trajectories for members of postcolonial societies as they navigate post-independence/globalization phenomena with the hope of creating stable, secure, productive and locally owned/managed contexts. While this constructive activity is important for decolonial thought, its seeming implication that there is an epistemic location outside of the colonial matrix from which it can be critiqued as a space to create alternatives, is rejected by decolonial thought. Indeed, for decolonial thought, one must make the clear distinction between colonialism and coloniality - the former a period of occupation and the latter, the epistemic structures that remain long after the period of occupied colonialism has ended.

As you can no doubt determine, the tasks of developing a decolonial form of theologizing require great humility and significant adjustments in theological epistemologies and perspectives. Though sociology and some philosophies have embraced this, it still remains a developing notion in theology. I know my colleagues and I in the WFTL are engaging this ${ }^{11}$ and there are others in the academy around the

10 Cf. Franz J. Hinkelammert, "Changes in the Relationships between Third World Countries and First World Countries," in Spirituality of the Third World: A Cry for Life, ed. K.C. Abraham and Bernadette Mbuy-Beya, (Maryknoll, NY: Orbis Books, 1994), 9-19; Gayatri Spivak, Critique of Postcolonial Reason: Toward a History of the Vanishing Present (Cambridge, MA: Harvard University Press, 1999), 191.

11 Jean-François Roussel, ed., Decoloniality and Justice: Theological Perspectives (São Leopoldo: Oikos, 2018); Ada María Isasi-Diaz and Eduardo Mendieta, eds., Decolonizing 
world working in this area because we see in decolonial thought opportunities to describe the social/political/economic/cultural situations in which we find ourselves, as well as opportunities to create alternative epistemologies. This is happening in reflections on race, ${ }^{12}$ gender ${ }^{13}$ and migration studies ${ }^{14}$ as these are areas decolonial thinkers explore in terms of the coloniality of power and living in pluriversal, intersectional contexts, and more broadly in looking at civilizational changes ${ }^{15}$.

\section{Gender Power Differentials}

A former colleague of mine at Duquesne, Anne Clifford, ${ }^{16}$ some years ago did a good job of outlining the various phases of feminist activity and stopped just short of the ecofeminist movement which correctly points out the symbiotic relationship in our treatment of women and the environment. Forgive my graphic expression but we seem to be willing and able to rape women and our environment as tools of war and exploitation. What I have heard repeatedly from my colleagues around the world over the years, Kochurani Abraham of India, Luiza Tomita of Brazil, Diane Jagdeo (may she rest in peace) from Trinidad, Albertine Tshilibondi Ngoyi from the Congo, Mary Getui from Kenya, Denise and Elise Couture from Canada and many more, ${ }^{17}$ including my colleagues here in the USA, is the increase in the level and types of violence against women occurring today. Global estimates published by the World Health Organization $(\mathrm{WHO})^{18}$ indicate that about 1 in $3(35 \%)$ women worldwide have experienced either physical and/or sexual intimate partner violence or non-partner sexual violence in their lifetime. And those of us teaching in colleges and universities around the USA know that among undergraduate females $23.1 \%$, that's almost 1 in 4 , have experienced sexual violence on campus - and that is based on what is reported and volunteered information, so it could even be higher! Some of my colleagues think this is a backlash for the advances women have made in society coupled with the perception that this is done at the expense of males advancing. The hard-fought advances of women are clearly not on the backs of males and one is hard-put to find any woman's movement that is not at the same time inclusive of males and people of other sexual orientations.

Epistemologies: Latina/o Theology and Philosophy (New York: Fordham University Press, 2011).

12 Rufus Burnett, Jr., Decolonizing Revelation: A Spatial Reading of the Blues (Fortress Academic, 2018).

${ }^{13}$ Maria Lugones, “The Coloniality of Gender", in Worlds and Knowledges Otherwise (vol 2, dos 2, Spring 2008) 1-17.

${ }^{14}$ Gemma Tulud Cruz, Toward a Theology of Migration: Social Justice and Religious Experience (Palgrave MacMillan, 2014).

${ }^{15}$ Lee Cormie, "New Heavens/New Hells", in Gerald M. Boodoo, ed., Religion, Human Dignity and Liberation (São Leopoldo, Oikos, 2016) 265-280; \ Lee Cormie, "Religious Resurgence in the Anthropocene", in Religion and the Politics of Integral Justice, ed. Gerard M. Boodoo, forthcoming 2019.

${ }^{16}$ Anne Clifford, Introducing Feminist Theology (Maryknoll, NY: Orbis Books, 2000).

${ }^{17}$ See the section "Gender, Feminisms and Equality" in Gerald M. Boodoo, ed., Religion, Human Dignity and Liberation (São Leopoldo: Oikos, 2016).

18 "Violence Against Women," Fact Sheets, World Health Organization, https://www.who.int/news-room/fact-sheets/detail/violence-against-women. 
So, it seems that the main driver of this violence is power and its use. I remember in the early 2000s Diane Jagdeo ${ }^{19}$ responding to part of a presentation I did in the Caribbean where I favored kenosis over dynamis in response to some social issues. She pointed out that for women in the Caribbean, dynamis, force, power, is necessary to survive as well as to engage the reality they have to face on a daily basis. The equitable distribution of power remains a significant problem in gender relations throughout our world. Thus far, our theological models have not been able to find ways to resolve this. If anything, despite the excellent work of many of our theologians, our prevalent theological and ecclesial structures remain entrenched in, on the one hand voicing support for change but on the other, partaking in social, economic, political and religious decisions that bespeak the former. This lack of consistency, even in a measured approach, helps to stoke the raging fires that give rise to the violence against women that we continue to experience today.

Some interesting developments in decolonial and indigenous perspectives present gender as also part of the colonial matrix ${ }^{20}$ and assert local perspectives such as the two spirit, third and fourth gender (and more) conceptions of indigenous peoples, ${ }^{21}$ that do not assign meaning to sexual anatomical differences from the binary (man/woman) understanding still being used in conceptions of gender. A must read is Oyerinke Oyewumi's text The Invention of Women: Making an African Sense of Western Gender Discourses $^{22}$ where she argues for an egalitarianism generated by the local and indigenous context that can be non-gendered and which need not use as its starting point the colonial imagination of male domination and female subordination.

\section{Perspectives on the Environment and its Degradation}

Many of the places I have visited over the years in Africa, Asia, Latin America, and the Caribbean, as well as here in the USA and Canada, have experienced natural disasters (earthquakes, flooding, wildfires, landslides, etc.) at various magnitudes, and the effects of human aided environmental degradation over the years. I know of this first-hand, being a native of Trinidad as well as being dislocated from New Orleans by Hurricane Katrina in 2005. Increasingly, natural disasters are more potent and affect more people. Local communities and smaller nations face the brunt of these events and the poorer and less resource wealthy you are, the more you are affected and the harder

${ }^{19}$ Unplublished presentation by Sr. Diane Jagdeo, O.P., "Women and Caribbean Theology" at the $10^{\text {th }}$ Anniversary Conference of the Conference on Theology in the Caribbean Today, 2003.

${ }^{20}$ Maria Lugones, “The Coloniality of Gender", Worlds and Knowledges Otherwise 2, no. 2 (Spring 2008): 1-17.

21 Vance Blackfox, "What I am," Ecclesio (blog), March 21, 2014, http://www.ecclesio.com/2014/03/what-i-am-vance-blackfox; Michael J. Horswell, "Toward an Andean Theory of Ritual Same-Sex Sexuality and Third-Gender Subjectivity," in Infamous Desire: Male Homosexuality in Colonial Latin America, ed. Pete Sigal (Chicago: The University of Chicago Press, 2002); Will Roscoe, Changing Ones: Third and Fourth Genders in Native North America (New York: Palgrave MacMillan, 2000).

22 Oyerinke Oyewumi, The Invention of Women: Making an African Sense of Western Gender Discourses (Minneapolis, University of Minnesota Press, 1997). 
it is to come back. In some cases, as in Montserrat in 1995 with the eruption of the volcano Soufriere, one never really comes back since most of the island was evacuated and today only around 5000 people inhabit the island. Hurricane Maria, in 2017, devastated islands in the Caribbean and the island of Dominica underwent damage of historic proportions, but is using the tragedy as an opportunity to build the first climate resilient country in the world.

Climate change, including our contribution to it, is creating food insecurity, dislocations and migrations, economic hardship, questions about energy policy, but most importantly it is leading to the loss of habitat for humans and other species. The deoxygenation of the oceans is causing shores in the Caribbean to be inundated by seaweed and contributing to the loss of coral reefs and the fish that live there. I recently visited my primary care physician who lived as a teen on the island of St. Thomas and he remembers diving and snorkeling among the reefs that were bright with color and teeming with fish and sharks (predominantly barracuda). He revisited some weeks ago and mentioned that he wondered why they did not tell folk diving at the reef to take off anything that sparkles, like watches and jewelry. When he dove and swam around for a bit he realized why, there weren't any sharks around to be attracted to the bling because there were not many fish in the reefs, which were themselves much less bright and healthy than he remembered. This can be repeated all around the Caribbean with noticeable degradation in the coral reefs. Add to this the dumping of human and radioactive waste and the plastic pollution found in our oceans and we have a recipe for lasting disaster. Things are not much better on land.

Environmental and ecotheological perspectives have become more important for many local contexts as they try to understand how ecosystems and faith perspectives can merge to create more healthy environments, institutions and spiritualities that allow all in the ecosystem to be sustainable and thrive. The search for renewable and sustainable energy and environmental models is also the search for renewed human dignity and hope. ${ }^{23}$ Ecotheology informed by local perspectives is not a choice made for a fashionable book publication or journal article, it is a necessary endeavor because climate change and natural disasters continue to create situations that bend, break and destroy the lives of our ecosystems.

\section{Interfaith/religious Relations}

You may have noticed that I did not use the word "dialogue" in the section header because I think this is peculiar to societies dominated by one religion and used by the dominant religion as a means to get a hold of other non-dominant religious expressions. Instead I prefer "relations" because that is how religions in multi religious societies engage each other. I grew up in such a society in Trinidad and it is commonplace for Hindus, Muslims, Catholics, Presbyterians, Rastafarians and others to share each other's feast and attend the same school, whether Christian or Hindu. It is commonplace in some parts of Caribbean (e.g., Jamaica) to find a Hindu as the

${ }^{23}$ See the sections "Interfaith/Religious Dialogue and Ecological Mobilization for Justice and Peace" and "Indigenous Peoples, Religions and Human Dignity" in Boodoo, ed., Religion, Human Dignity and Liberation. 
principal of a Catholic high school or someone of another denomination championing and leading a particular denominational school. More often than not, it is the institutional religious structures and traditions and their will to power that prevent full religious integration and spiritual intersectionality. ${ }^{24}$ In general, relations among people and thinkers of different faiths and religions exhibit reflexivity and continue to nurture all of our faiths and religions. After all, I am not aware of any of our religions today that did not arise out of another or blend of other religions (e.g. Christianity from Judaism), so they are inherently interreligious, though we like to pretend otherwise.

One aspect of this area that is gaining more traction however is our relations to indigenous people and their cosmologies. ${ }^{25}$ For far too long their contexts and epistemologies have been inferiorized and subjugated, and the myth of their extinction has been over exaggerated. Our attempts to deny them have ranged from claiming that they no longer exist in identifiable groups, to them not having viable religions, to their being animistic and primitive, to questions of their identity as valid members of their group. The question of who, what, where is the indigenous and their right to selfdetermination remain political and economic flashpoints, but they can no longer be ignored and theologians cannot dismiss nor only work to subsume their cosmologies into a fulfillment model for Christianity. Theologians all over the world make the claim that God was present in their regions before Christianity was brought. This means more than simply a preparation for an imperial colonial religiosity! Especially when these indigenous expressions have exhibited, in the most part, spiritual hospitality in allowing spaces for other gods and religions. Perhaps we need to recover the indigenous contexts out of which Christianity arose, the network of indigenous groups

${ }^{24}$ A good example of this is the La Divina Pastora/Suparee Ke Mai devotions of Trinidad, celebrated by Christians (not only Catholics) and Hindus/Muslims. See Gerald M. Boodoo, "The Faith of the People: The Divina Pastora Devotions of Trinidad", in Religion, Culture and Tradition in the Caribbean, ed. Hemchand Gossai and Nathaniel Samuel Murrell (New York: St. Martin's Press, 2000); The Madonna Murti (documentary), directed by Oyetayo Raymond Ojoade, written by Sharion Syriac (Trinidad, 2013); Teruyuki Tsuji, “"They don't do culture': Mother Kali as a Matrix of National Culture in Trinidad," Wadabagei: A Journal of the Caribbean and Its Diasporas 12, no. 3 (2009): 59-86.

${ }^{25}$ Michel Andraos, ed., The Church and Indigenous Peoples in the Americas: In Between Reconciliation and Decolonization (Eugene, OR: Cascade Books, 2019); Elochukwu Uzukwu, God, Spirit, and Human Wholeness: Appropriating Faith and Culture in West African Style (Eugene, OR: Pickwick Publications, 2012); Elochukwu Uzukwu and Akuma-Kalu Njoku, eds., Interface Between Igbo Theology and Christianity (Newcastle upon Tyne, UK: Cambridge Scholars Publishing, 2014); Eleazar López Hernández, "Towards a Theology of Ecology from and Indigenous Perspective," in Religion, Human Dignity and Liberation, ed. Gerard M. Boodoo, (São Leopoldo, Oikos, 2016), 191-195; Gerald M. Boodoo, "Liberation and Indigenous Peoples: Who, What, Where Is Indigenous?" in Religion, Human Dignity and Liberation, ed. Gerard M. Boodoo, (São Leopoldo, Oikos, 2016),179-190; Elise Grondin-Couture, "Transforming the Idea(l) of Justice: Readiing Stories by Indigenous Women as a Feminist Settler" in Religion and the Politics of Integral Justice, ed. Gerald M. Boodoo, forthcoming 2019. 
of the pre-Israelites. ${ }^{26}$ It always fascinates me that Christianity in the conquest of the Americas and Africa was quick to label indigenous populations there as cannibalistic and therefore inferior and backward, when to date, there is no archeological evidence to support this except in some cases of ritual sacrifice. Yet this same religion, Christianity, demands that its followers eat the body and drink the blood of its God who became human on as regular a basis as possible. So, one form of ritual cannibalism is better than another?

\section{Avenues of Promise: Gifts from Local Theologies}

In this final and brief concluding section I want to make two suggestions of what I consider to be avenues of promise gifted to us by local theologies especially in light of the overall theme of this conference Another World Is Possible: Violence, Resistance and Transformation, which uses the Zapatista phrase taken up as the mantra of the WSF that "Another World is Possible" and the theme of the most recent WSF and WFTL meeting in Salvador da Bahia last year, "Resist and Create; Resist and Transform."

The first gift, is that by the very nature of locality (and we all, including our religions, are local in nature) we are partial, in the sense that we do not have the whole picture and therefore our traditions are partial and cannot give us the whole picture. Chimamandah Adichie in her famous TED Talk on "The Danger of a Single Story" makes this point very well. ${ }^{27}$ The reality is that we do not have "pure" and complete traditions and the partiality of our traditions, including the Catholic traditions (plural, not singular) require other traditions in the search for completion.

A thinker in the Caribbean I admire, Wilson Harris, speaks of the "numinous partiality" 28 we present in our historical and fictional expressions that allow us to "arrive in tradition."

Indeed, in this scenario we come abreast of the self-deceptions in a purely formulaic (some would say Cartesian) education, in which a so-called dialogue with the past rests on descriptions of, not numinous arrival in, the complex, disturbing life of tradition. ${ }^{29}$

$\mathrm{He}$ is arguing here against the retrieval of some magical, "pure", original consciousness, or calcified structure, which is presupposed with dominant historical descriptions. Instead, to arrive in tradition "involves an appreciation of profound

${ }^{26}$ Steven Battin, "Resurrection of Jesus as Resurrection of the Ancestors: A Hermeneutic Prologue to Epistemic Decoloniality in Christian Theology", Decoloniality and Justice: Theological Perspectives, ed. Jean-François Roussel (São Leopoldo: Oikos, 2018), 73-82.

${ }^{27}$ Chimamanda Ngozi Adichie, “The Danger of a Single Story,” TED Talks, July 2009, https://www.ted.com/talks/chimamanda_adichie_the_danger_of_a_single_story

28 Wilson Harris, "Creoleness: The Crossroads of a Civilization?," in The Unfinished Genesis of the Imagination: Selected Essays of Wilson Harris, ed. Andrew Bundy (New York: Routledge 1999) 247.

${ }^{29}$ Harris, "Creoleness," 243. 
tension between originality and tradition. ${ }^{30}$ There is in this understanding a deep sense of owning and appreciating the partiality of any interpretation. How will Christian narratives, imperial narratives, colonial narratives, dominating narratives fare in such an exercise when their aims and goals are toward total description? None of these aforementioned narratives lay claim to partiality nor are they interested in doing so. How would Christianity be understood with such claims of partiality? Theological and dogmatic expressions recoil at this because of the specter of relativism. Perhaps we have given that term a bad rap by not embracing the partiality of our local histories. I quote Harris again,

There can be no perfect or absolute arrival in tradition, and some measure of descriptive logic is necessary; but we need a narrative that helps us to sense the partiality of linear progression and brings home to us in genuine stages of creativity (rather than purely intellectual experimentation) the simultaneity of the past, present and the future in the unfinished genesis of the imagination. ${ }^{31}$

This arriving in tradition depends on our use of the arts of the imagination which seem to have been shunned in the technologically driven modern age. In our rush to invest absolutely in partial traditions (modernity, coloniality, religious economies) we do not partake of the creative capacity to "read ourselves in the book of reality...as partial creatures." ${ }^{" 32}$ Instead of arriving in tradition, we encapsulate it with descriptors that make us essential to its existence. We become not just necessary to the tradition, we become the tradition itself! A new theological reading from the local partiality of our contexts, struggling with the tension between originality and tradition that addresses the heart of our presuppositions, must work with our imaginative capacity for re-creative genius. It also requires bravery and trust in the Spirit. Can our theological traditions adjust their seemingly unlimited hubris and arrive in tradition as partial readings rather than claim to be the tradition(s)?

The second gift is that location is significant for local theologies, and by location I mean geography, space, land, place. Our obsession in modernity with temporality seems to allow us to neglect the specificity of spatial realities and reduce them to signification and transcendental possibilities that we need not substantially engage, and that we can universalize. Perhaps the expanding engagement with indigenous cosmologies is helping to emphasize this point but we do need to begin shifting our gaze to a/the spatial turn in theology ${ }^{33}$ and to what it means to prioritize spatial readings in our theologizing. Vine Deloria mentioned this years ago for the North American context and, increasingly, local theological reflections are asking us to attend to their space, understand their land, share but don't dominate their place. I refer to this turn to

${ }^{30}$ Harris, "Creoleness," 243.

${ }^{31}$ Harris, "Creoleness," 244.

${ }^{32}$ Harris, "Creoleness," 247.

${ }^{33}$ Sigurd Bergman, "Theology in its Spatial Turn: Space, Place and Built Environments Challenging and Changing the Images of God," Religion Compass 1, no. 3 (2002): 353-379; see also a special section of the Annals of the Association of American Geographers (96, no. 1 (2006): 169-202; Bruce B. Janz, ed., Place, Space and Hermeneutics (Geneva: Springer, 2018). 
the spatial as developing spatial theological flows. Robert Schreiter used the term "flow" some years ago to speak of what he called global flows to describe in broad strokes responses to the effects of globalization. According to Schreiter, flows can be understood as discourses, epistemologies and activities, that, while not uniform or systemic, represent a series of linkages that are mutually intelligible. They are not uniform or systemic, because of their commitment to specific cultural and social settings. Yet they are intelligible to discourses, epistemologies and activities in other cultural and social settings that are experiencing similar problems and exhibiting similar responses. ${ }^{34}$

I use the term in a similar manner but with the recognition that one can move in and out of spatial epistemological flows and that to remain within it requires continually adjusted epistemological intentionality in prioritizing space. What I mean and understand by spatial epistemological flows is a work in progress for me but I do know that it gives theology alternatives to its current temporally bound epistemologies. It is a difficult de-linking and re-linking to accomplish but it gives theology the ability to resist epistemic locations that stifle transformation and locates us in spaces that provide glimpses of another possible world. This is always reflexively exposed when we have to adjust to languages arising out of contexts that differ cosmologically and spatially, so, I will end by referencing a prayer that is the bedrock of Christianity but spoken in the Arawakan language of the Tainos who inhabited the bigger islands of the Caribbean.

Guaki'a baba, turey toca (Our father [in the] quietness or stillness of the sky) Guami'ke'ni (lord of island and water), guami'karaya guey (lord of moon and sun)

Gua'rico guaki'a (come to us)

Taino ti bo matu'm (good, high big and generous/friendship), Busica guaki'a (to give to us)

Yucubia aje casabi (tubers/plants, cassava bread)

Hu'raca'n ua' (hurricane/bad spirit no), mabuya ua' (ghost of an evil spirit no), Yuke'io han (rainforest/good spirit [of the mountain] yes),

Naboria daca (servant am I),

Han ha'n catu' (So be it/Yes let it be this way).

${ }^{34}$ Robert J. Schreiter, The New Catholicity: Theology between the Global and the Local (Maryknoll, NY: Orbis Books, 1997), 16. 